TEME, г. XLI, бр. 2, април - јун 2017, стр. 535-537

Приказ дела

DOI: 10.22190/TEME1702535S

Примљено: 24. 03. 2017.

Одобрено за штампу: 15. 06. 2017.

\title{
DEVELOPMENT AND APPLICATION OF MOBILE BANKING CONCEPT *
}

\author{
Milena Stanković \\ University of Niš, Faculty of Electronic Engineering, Niš, Serbia \\ milena.stankovic@elfak.ni.ac.rs
}

Intensive development of information technology in recent years has been especially prevalent in the area of mobile and wireless communications. The number of users of mobile phones and other wireless devices is constantly growing at very high rates. Mobile network operators invested significantly in improving communications and the development of new technologies and services. Increasing the number of mobile operators, increasing rates of mobile phone use and increasing the number and quality of banking services provided through the Internet are the main reasons for the strong growth of mobile banking. Mobile banking is seen as a model of e-business of banks and mobile network operators using the mobile telecommunication networks in order to provide banking services to customers via their mobile devices. This model allows mobile banking payments, control of account balances, taking loans and a range of other financial services and transactions.

Slavoljub Milovanović, Professor of The Faculty of Economics, University of Niš, in his monograph study, entitled "Development and application of the concept of mobile banking" presents a detailed analysis of models and services of mobile banking, their advantages offered to customers, banks and mobile network operators and proposes appropriate technological solutions in the form of architecture and applications of mobile banking. A special significance in this study has the analysis of the regulatory and security issues of whose solutions the survival and development of individual models and services of mobile banking depend. In addition, the author of this study presents the latest trends in mobile banking in the developed countries and points to the problems and challenges of mobile banking faced by the developing countries.

In this study, the author started from a few assumptions. First, the implementation of mobile banking services allows banks to retain the existing and attract new customers. Second, mobile network operators are becoming increasingly important mobile banking entities who assume the role of banks in providing mobile financial services to their clients. Third, different models of mobile banking allow customers who have accounts in banks an easier and more efficient management of

\footnotetext{
* Slavoljub Milovanović (2016). Development and Application of Mobile Banking Concept, Nis: The Faculty of Economics in Niš, p., 125.
} 
these accounts, while the users who do not have bank accounts can possess and manage mobile (virtual) money. Fourth, good regulation in the telecommunications and banking has a positive impact on the development of mobile banking and protection of mobile banking customers. Finally, mobile banking software applications are becoming easier and easier to use, which positively affects the growing acceptance of mobile banking services by mobile users.

Since the subject of the research in this study refers to the models and services of mobile banking in the context of technologies and applications that enable them, to the regulatory framework of mobile banking, security issues and possible answers to them, the study is organized into six chapters.

In the first chapter, The development of mobile technologies and electronic business (pp. 4-12), author explains the modern generations of mobile technologies and mobile applications that are the foundation of mobile business, commerce, and banking. In the second chapter, The mobile banking models (pp. 13-30), models and operators of mobile banking are explained. It gives a classification of these models, as well as the advantages and disadvantages of different categories of the models.

The third chapter, Mobile financial and banking services (pp. 31-52), is dedicated to mobile financial and banking services. Special attention is paid to the services of mobile payments and mobile money transfer. The fourth chapter, Technology architecture and applications to support m-banking, (pp. 53-75), presents the technological architecture to support mobile banking services and analyzes the characteristics of mobile banking applications. In addition, examples of applications and services in mobile banking practice of Intesa bank are presented.

In the fifth chapter, Regulatory and security dimension of m-banking (pp. 76-95) the author discusses the key regulatory issues and the regulatory framework for mobile banking. Also the author analyses the problem of security of mobile banking and provides principles and recommendations for improving the security of mobile banking in the field of mobile payments, mobile applications and networks. Finally, in the sixth chapter, Challenges and trends of m-banking services in developed and developing countries (pp. 96-114), the author analyzes the latest trends in mobile banking in developed countries, as well as the challenges faced by the developing countries when it comes to this form of banking.

The results of the research presented in this study can be used by researchers in a deeper study of the services and models of mobile banking implementation and different technological alternatives that can support the implementation. In addition, the practical significance of this study is to present all the advantages that mobile banking entities can receive (banks and mobile operators) by implementation of suitable alternative and their customers using mobile banking services via their mobile devices. Practical significance of this research is expressed through the analysis of practical examples of using mobile banking applications.

In the end, it can be concluded that this monographic study fulfilled the planned expectations: to present the most important advantages of mobile banking, both from the user's perspective and from the perspective of banks and mobile network operators; to analyze the main categories of mobile banking and financial services, with special emphasis on the services of mobile payments and mobile money transfer; to explain the features, advantages and disadvantages of different models of mobile banking, as well as the possibility of their implementation; to present the most important regulatory and security issues on which the functioning of mobile banking depends and to propose options for solving them; to analyze the 
technological alternatives relating to the implementation of the architecture and applications of mobile banking; to explain the latest trends in mobile banking in the developed countries, and the challenges faced by the developing countries when it comes to this form of banking. 